\title{
KRISIS KEUANGAN DI DUNIA BERKEMBANG \\ - PASCA “BENCANA PENGGELEMBUNGAN HARGA ASET" AS - JALAN BARU KE DEPAN
}

\author{
Nn. Sagarika Chakraborty ${ }^{1}$ \\ Tn. Soumya Banerjee
}

\begin{abstract}
A bstract
This paper analyze how we should respond to possible asset price bubbles, especially in view of the various conceptual frameworks proposed based on a core set of scientific principles for monetary policy. Further, efforts have also been made at my end to establish as to how Monetary policy should not react to asset price bubbles per se, but rather to changes in the outlook for inflation and aggregate demand resulting from asset price movements. However, regulatory policies and supervisory practices should respond to possible asset price bubbles and help prevent feedback loops between asset price bubbles and credit provision, thereby minimizing the damaging effects of bubbles on the economy.

The general massage of this paper is that credit conditions influence economies enormously and emergency steps to restructure balance sheets through policy revamping are crucial for fixing problems of excessive leverage. This stands in sharp contrast to the view from conventional models - that 'the effects of a worsening of financial intermediation are likely to be limited' and can be handled by interest rate cuts alone.

In the alternative regulatory policy approach, we have strived to examine three possible regulatory responses to managing bubbles: portfolio restrictions; adjustments in capital requirements; and adjustments in provisioning requirements.
\end{abstract}

Keywords: financial crisis, asset price bubble.

JEL Classification: E58, E63, G15

1 Ms. Sagarika Chakraborty, Legal Manager, Corporate Legal Group, ICICI Bank Limited, Kolkata, India and Mr. Soumya Banerjee, Legal Manager, Corporate Legal Group, ICICI Bank Limited, Kolkata, India. 


\section{PENDAHULUAN}

Perkembangan ekonomi telah menjadi bahan perdebatan besar terutama terkait dengan penggelembungan harga aset. Dengan meninjau pengalaman-pengalaman sebelumnya, pecahnya (burst) gelembung aset (asset bubble) di pasar perumahan seringkali dikaitkan dengan krisis ekonomi yang parah, terutama, pasca resesi yang disebabkan oleh penurunan pengeluaran secara tajam akibat hilangnya daya beli konsumen untuk mengimbangi pendapatan modal.

Jauh sebelum krisis keuangan yang melanda dunia saat ini penelitian Dana Moneter Internasional (IMF) yang dilaporkan dalam World Economic Outlook tahun 2003 mengindikasikan bahwa kerugian output setelah terjadi krisis harga perumahan di negara-negara maju, secara rata-rata, dua kali lebih besar daripada kerugian setelah krisis pasar saham, yang biasanya menimbulkan resesi yang lama. ${ }^{2}$

Dengan melihat skenario di atas, artikel ini ingin menganalisa bagaimana kelemahan (loophole) yang ada dalam undang-undang di berbagai negara menimbulkan ancaman yang lebih besar di tahun-tahun mendatang akan adanya penurunan ekonomi yang parah dan bagaimana Diaspora tersebut akan mempengaruhi negara-negara berkembang serta stabilitas ekonomi mereka di peta dunia. Menurut R. Kannan dari Reserve Bank of India, harga saham menjadi indikator utama dari inflasi, meskipun hal ini kurang memiliki daya prediktif dalam hal kesenjangan output, dan karenanya, dengan mengambil contoh dari studi kasus tersebut adalah penting untuk menganalisa "tren penggelembungan (bubble trend)" dari masing-masing negara untuk merancang rencana pemberian dana talangan (bail out) yang tepat dan untuk membangun ekonomi yang stabil demi menghindari kemunduran di masa mendatang.

Untuk mencapai tujuan ini, kami menganjurkan undang-undang anti-penggelembungan (anti-bubble law) di berbagai negara berkembang, yang serupa dengan di negara kami, India yang saat dianalisa sesuai dengan template dan peta dalam penelitian mikroekonomi dan makroekonomi tentang pembentukan bubble dan mengajukan kerangka regulasi dibandingkan dengan "kebijakan moneter" tradisional untuk semua pendekatan.

Artikel ini juga memastikan mengapa penggelembungan harga aset bisa timbul dari kegagalan pasar yang menyebabkan terjadinya maraknya (boom) kredit dan regulasi yang bisa mencegah feedback loop antara penggelembungan harga aset dan pemberian kredit dengan bantuan kebijakan regulasi yang mengatur Bank-Bank.

2 International Monetary Fund's report in World Economic Outlook, titled, "Growth and Institutions ", published in April 2003, available at http://www.imf.org/external/pubs/ft/weo/2003/01/index.htm 


\section{MONOLOG HISTORIS}

Bull market dan gairah pasar (exuberance) yang panjang yang terkait dengan boom ekonomi baru pada tahun 1990an terhenti pada tahun 2000. Sejak itu, indeks harga ekuitas di negara-negara industri menurun tajam dan terus mengalami penurunan dan karenanya, untuk memahami sifat kerja bubble ini adalah penting untuk menganalisanya dengan melihat latar belakang historis dan alasan yang mendasari kemunculan bencana tersebut.

Konsep penggelembungan harga aset sebagai suatu dilema yang baru berkembang di berbagai negara adalah suatu hal yang salah. Penggelembungan harga telah ada sejak pertengahan abad ke-17 dan meskipun sektor-sektor yang terpengaruh oleh bubble berbeda namun alasan dasarnya kurang lebih masih tetap sama. Jika digabungkan dengan istilah "gelembung ekonomi (economic bubble)" (yang bisa dikatakan mencakup speculative bubble, market bubble, price bubble, financial bubble, atau speculative mania) maka istilah ini mengacu pada, dalam bahasa sederhana, "perdagangan volume tinggi pada harga yang berbeda dengan nilai intrinsiknya. ${ }^{3}$

Gambaran singkat tentang sejarah penggelembungan harga aset bisa dirangkum dalam tabel berikut ini:

\begin{tabular}{|c|c|c|}
\hline Tahun & $\begin{array}{c}\text { Biasanya disebut } \\
\text { sebagai }\end{array}$ & Penjelasan Singkat \\
\hline 1637 & $\begin{array}{l}\text { TULIP MANIA atau } \\
\text { TULIPOMANIA }\end{array}$ & $\begin{array}{l}\text { Ini pada dasarnya merupakan speculative bubble pertama yang pernah } \\
\text { tercatat semasa Era Keemasan Belanda dimana harga kontrak bonggol (bulb) } \\
\text { tulip yang baru diperkenalkan mencapai tingkat yang luar biasa tinggi dan } \\
\text { kemudian tiba-tiba jatuh. Pada puncap tulip mania pada bulan Februari } \\
1637 \text {, kontrak tulip terjual lebih dari } 10 \text { kali lipat dari pendapatan tahunan } \\
\text { pengrajin. }{ }^{4}\end{array}$ \\
\hline 1720 & SOUTH SEA BUBBLE & $\begin{array}{l}\text { South Sea Company adalah perusahaan saham gabungan Inggris yang } \\
\text { diperdagangkan di Amerika Selatan pada abad ke- } 18 \text {. Spekulasi dalam } \\
\text { saham perusahaan menimbulkan economic bubble yang sangat besar yang } \\
\text { dikenal dengan sebutan South Sea Bubble pada tahun } 1720 \text {, yang } \\
\text { menyebabkan kehancuran keuangan bagi banyak pihak. }{ }^{5}\end{array}$ \\
\hline
\end{tabular}

3 King, Ronald R.; Smith, Vernon L.; Williams, Arlington W. and van Boening, Mark V. (1993). "The Robustness of Bubbles and Crashes in Experimental Stock Markets". in R. H. Day and P. Chen. Nonlinear Dynamics and Evolutionary Economics. New York: Oxford University Press. ISBN 0195078594. Also see, Lahart, Justin (2008-05-16). "Bernanke's Bubble Laboratory, Princeton Protégés of Fed Chief Study the Economics of Manias". The Wall Street Journal: p. A1. avaialbe at http://online.wsj.com/article/ SB121089412378097011.html.

4 Tulipomania: The Story of the World's Most Coveted Flower \& the Extraordinary Passions It Aroused." Mike Dash (2001).

5 John O'Farrell, An Utterly Impartial History of Britain - Or 2000 Years of Upper Class Idiots In Charge (October 22 2007) (2007, Doubleday, ISBN 978038561 1985). Also, see Charles Mackay, Extraordinary Popular Delusions and the Madness of Crowds (Harriman House Classics 2003), p. 65 \& 71. 


\begin{tabular}{|c|c|c|}
\hline Tahun & $\begin{array}{c}\text { Biasanya disebut } \\
\text { sebagai }\end{array}$ & Penjelasan Singkat \\
\hline 1840an & RAILWAY MANIA & $\begin{array}{l}\text { Salah satu speculative bubble Inggris yang paling banyak dibahas yang } \\
\text { mengikuti pola yang sama: seiring dengan peningkatan harga saham rel } \\
\text { kereta api, makin banyak uang yang digelontorkan oleh para spekulan, } \\
\text { sampai akhirnya terjadi kejatuhan yang tak terhindarkan. Hal ini mencapai } \\
\text { puncaknya pada tahun } 1846 \text {, saat tak kurang dari } 272 \text { Undang-Undang } \\
\text { Parlemen dikeluarkan, mendirikan perusahaan-perusahaan rel kereta api } \\
\text { baru, dan rute yang diajukan mencapai total } 9.500 \text { mil ( } 15.300 \mathrm{~km} \text { ) dari } \\
\text { rel kereta api baru. Sekitar sepertiga rel kereta api yang disahkan tidak } \\
\text { pernah dibangun baik karena perusahaan mengalami kejatuhan karena } \\
\text { perencanaan keuangan yang buruk, atau karena dibeli oleh kompetitor } \\
\text { yang lebih besar sebelum perusahaan bisa membangun rel kereta, atau } \\
\text { karena ternyata perusahaan tersebut merupakan perusahaan fiktif untuk } \\
\text { menyalurkan dana investor ke usaha lain. }{ }^{6}\end{array}$ \\
\hline 1920an & $\begin{array}{l}\text { FLORIDA LAND } \\
\text { BOOM }\end{array}$ & $\begin{array}{l}\text { Florida land boom pada tahun 1920an merupakan real estate bubble } \\
\text { pertama yang dilaporkan, yang meledak pada tahun 1925, meninggalkan } \\
\text { seluruh kota-kota baru dan sisa-sisa dari proyek pembangunan yang gagal. } \\
\text { Apa yang tadinya dimulai dengan laporan gila-gilaan yang mengklaim } \\
\text { "It's June In Miami - Ini Bulan Juni di Miami", menimbulkan kenaikan } \\
\text { harga properti akibat spekulasi dan terjadilah boom lahan dan } \\
\text { pembangunan." }\end{array}$ \\
\hline 1970an & POISEDON Bubble & $\begin{array}{l}\text { Inilah stock market bubble pertama dimana harga saham tambang } \\
\text { Australia meningkat pada akhir tahun 1969, namun kemudian jatuh pada } \\
\text { awal 1970an. Hal ini dipicu oleh penemuan oleh perusahaan Poseidon NL } \\
\text { akan adanya situs tambang nikel yang menjanjikan pada bulan September } \\
\text { 1969. }\end{array}$ \\
\hline 1980an & $\begin{array}{l}\text { Gelembung } \\
\text { HARGA ASET } \\
\text { Jepang }\end{array}$ & $\begin{array}{l}\text { Pada dekade-dekade setelah Perang Dunia II, Jepang mengenakan tarif } \\
\text { dan kebijakan yang ketat untuk mendorong masyarakat untuk } \\
\text { menabungkan pendapatan mereka. Dengan adanya lebih banyak dana di } \\
\text { bank, pinjaman dan kredit menjadi lebih mudah diperoleh, dan karena } \\
\text { Jepang mengalami surplus perdagangan yang besar, yen terapresiasi } \\
\text { terhadap mata uang-mata uang asing. Hal ini memungkinkan perusahaan- } \\
\text { perusahaan lokal lebih mudah berinvestasi dalam sumber daya modal } \\
\text { dibandingkan dengan kompetitor mereka di luar negeri, yang kemudian } \\
\text { menurunkan harga barang-barang buatan Jepang dan makin memperlebar } \\
\text { surplus perdagangan. }{ }^{9} \text { Dan, karena yen terapresiasi, aset keuangan menjadi } \\
\text { sangat menguntungkan, yang menimbulkan economic bubble di Jepang } \\
\text { dari tahun } 1986 \text { sampai } 1990 \text {, dimana harga real estate dan harga saham } \\
\text { mengalami inflasi. }{ }^{10} \text { Kejatuhan bubble berlangsung lebih dari satu dekade } \\
\text { dimana harga saham sangat jatuh pada tahun } 2003 \text {, sampai mencapai } \\
\text { harga yang bahkan lebih rendah lagi di tengah krisis global pada tahun } \\
2008 \text {. }\end{array}$ \\
\hline
\end{tabular}

6 Wolmar, C, 2007, Fire \& Steam: A History of the Railways in Britain, Atlantic Book (London) ISBN 978-1-84354-629-0.

7 Kenneth Ballinger: Miami Millions, Miami: (self published), 1936. p. 139

8 Three Australian Asset-price Bubbles", The Reserve Bank of Australia, 2003. Available at http://www.rba.gov.au/ PublicationsAndResearch/2003/Simon.pdf.

9 Bank of Japan, "Asset Price Bubble in Japan in the 1980s: Lessons for Financial and Macroeconomic Stability" http://www.imes.boj.or.jp/ english/publication/edps/2003/03-E-15.pdf.

10 "Japan's Bubble Economy".http://www.sjsu.edu/faculty/watkins/bubble.htm. 


\begin{tabular}{|c|c|c|}
\hline Tahun & $\begin{array}{c}\text { Biasanya disebut } \\
\text { sebagai }\end{array}$ & Penjelasan Singkat \\
\hline 1997 & $\begin{array}{l}\text { KRISIS KEUANGAN } \\
\text { ASIA }\end{array}$ & $\begin{array}{l}\text { Periode krisis keuangan berlanjut pasca tahun } 1997 \text { yang tidak hanya } \\
\text { melanda Asia namun juga menimbulkan kekhawatiran adanya kejatuhan } \\
\text { ekonomi dunia karena merembetnya krisis keuangan. Krisis dimulai di } \\
\text { Thailand dengan jatuhnya baht Thailand yang disebabkan oleh keputusan } \\
\text { pemerintah untuk mengambangkan baht, memotong peg terhadap USD, } \\
\text { setelah berbagai usaha untuk menyokong baht dalam menghadapi } \\
\text { overextension keuangan yang parah yang sebagiannya disebabkan oleh } \\
\text { real estate. Pada waktu itu, Thailand memiliki beban utang luar negeri } \\
\text { yang menjadikan negeri itu secara efektif bangkrut bahkan sebelum } \\
\text { jatuhnya mata uang negeri tersebut. Saat krisis meluas, sebagian besar } \\
\text { Asia Tenggara dan Jepang mengalami kejatuhan mata uang, devaluasi } \\
\text { pasar saham dan harga-harga aset lainnya, serta kenaikan utang swasta. }{ }^{11}\end{array}$ \\
\hline $\begin{array}{c}2006 \\
\text { sampai } \\
\text { sekarang }\end{array}$ & $\begin{array}{l}\text { REAL ESTATE } \\
\text { BUBBLE }\end{array}$ & $\begin{array}{l}\text { Sejak tahun 2006, keberadaan real estate bubble atau krisis sub-prime } \\
\text { mortgage di seluruh dunia, telah menyebabkan para ekonom } \\
\text { mengkhawatirkan pola serupa di pasar real estate di berbagai negara, } \\
\text { yang pada dasarnya mencakup pola overvaluasi dan pinjaman dalam } \\
\text { jumlah banyak berdasarkan pada overvaluasi tersebut. Real estate bubble } \\
\text { ini diikuti dengan penurunan harga (disebut juga dengan krisis harga } \\
\text { perumahan) yang bisa menyebabkan banyak pemilik memiliki ekuitas } \\
\text { negatif dan dalam konteks sekarang hal inilah yang telah terjadi yang } \\
\text { menyebabkan negara-negara terdepan seperti India, Amerika Serikat, } \\
\text { Inggris, Jepang, Cina meyaksikan kenaikan valuasi properti riil seperti } \\
\text { perumahan sampai mencapai tingkat yang tak bisa dipertahankan lagi } \\
\text { dikaitkan dengan pendapatan dan elemen-elemen ekonomi lainnya. }\end{array}$ \\
\hline
\end{tabular}

Penelaahan dan pemeriksaan lebih mendalam tentang model penggelembungan harga aset di atas mengindikasikan bahwa kerugian output setelah kejatuhan harga perumahan di negara-negara maju, secara rata-rata, dua kali lebih besar dibandingkan kerugian yang terjadi setelah kejatuhan pasar saham, yang biasanya menimbulkan resesi berkepanjangan. ${ }^{12}$ Selain itu, kenaikan nilai saham perumahan yang disokong oleh kenaikan harga menyebabkan para analis bertanya-tanya apakah boom ini bisa bertahan ataukah hanya sekedar gelembung keuangan (financial bubble) besar yang siap meledak. Kenaikan harga perumahan secara global baru-baru ini berjalan berbarengan dengan kenaikan yang jauh lebih besar dalam utang perumahan daripada dalam boom sebelumnya. ${ }^{13}$ Bukan hanya pembeli baru yang meminjam mortgage yang lebih besar, namun bahkan pemilik lamapun telah meningkatkan jumlah mortgage mereka untuk mengubah keuntungan modal menjadi uang tunai yang menimbulkan perlombaan dalam harga perumahan.

11 Kaufman, GG., Krueger, TH., Hunter, WC. (1999). The Asian Financial Crisis: Origins, Implications and Solutions. Springer. ISBN 0792384725.

12 International Monetary Fund's report in World Economic Outlook, titled, "Growth and Institutions", published in April 2003, available at: http://www.imf.org/external/pubs/ft/weo/2003/01/index.htm

13 Identifying Asset Price Bubbles in the Housing Market in India - Preliminary Evidence, Reserve Bank of India Occasional Papers, Vol. 27, No. 1 and 2, Summer and Monsoon 2006. 
Dengan melihat tren saat ini, kenaikan di pasar perumahan di AS menjadi sumber kekhawatiran, terutama bagi stabilitas keuangan global. Dan meskipun perkembangan sektor perumahan merupakan suatu keuntungan, namun penting juga untuk mencatat kecepatan intensifikasi siklus tersebut dengan memandang besarnya risiko penggelembungan harga aset. Beberapa faktor yang berkontribusi terhadap terjadinya bubble adalah tingginya pertumbuhan kredit dibarengi dengan rendahnya suku bunga. Karenanya kasus-kasus historis tentang bencana harga aset merupakan hal yang berguna untuk melakukan analisa empiris tentang kajian kondisi saat ini di pasar perumahan dari sudut pandang negara-negara berkembang, pilihan kebijakan mereka terkait dengan pasar perumahan.

Dengan mengacu pada negara-negara berkembang seperti India, harus dipahami bahwa di negara-negara tersebut penelitian empiris tentang pasar perumahan jarang ditemukan karena kurangnya informasi. Dengan tujuan untuk mengisi kekosongan ini, bab-bab selanjutnya dalam artikel ini berusaha untuk secara teoritis menganalisa penggelembungan harga perumahan di India - terutama dengan tujuan untuk memisahkan elemen harga riil dari elemen harga spekulatif dan berfokus pada agregat moneter yang relevan yang berpengaruh pada pertumbuhan pasar perumahan.

\section{KEKHAWATIRAN DI BALIK "BENCANA PENGGELEMBUNGAN HARGA ASET"}

Ada berbagai faktor penting dalam pertumbuhan pasar perumahan terutama terdiri atas pertumbuhan pendapatan, kebijakan moneter, perpajakan dan insentif regulasi serta kemudahan prosedur pemberian pinjaman, dll. Di sisi lain, faktor-faktor spekulatif bergantung pada propaganda terkait dengan iklan, informasi asimetris dan perilaku spekulatif atau perilaku bersama yang menyebabkan harga naik sampai tingkat yang tidak bisa dipertahankan yang diluar itu kemudian ditentukan oleh faktor-faktor yang disebutkan di atas. Meskipun sulit untuk mengkategorikan penggelembungan harga perumahan, yang terjadi karena deviasi harga pasar dari nilai dasar rumah, namun ada sejumlah pendekatan eklektik yang efektif untuk melakukan identifikasi.

Salah satu kekhawatiran lain timbul dari model yang diajukan oleh Ball (1999), dimana dia menyatakan bahwa keberadaan penggelembungan harga aset belum terlihat sampai siklus tertentu telah terlampaui. Dalam matriksnya, dia mengasumsikan kerangka waktu 2 tahun untuk bisa memastikan keberadaan penggelembungan harga dengan keyakinan. Dia menganalisa bahwa pengetatan kebijakan moneter sebelum seluruh siklus ini berakhir, awalnya mungkin akan membatasi pertumbuhan bubble namun kemudian menyebabkan para investor 
percaya bahwa krisis telah berakhir. Akan tetapi, Ball menyatakan bahwa gambaran indah ini hanyalah suatu ilusi, karena setelah kebijakan moneter menjadi biasa lagi; ekonomi akan kembali turun dan karenanya memicu lingkaran setan ini kembali. Jelas bahwa Ball seperti halnya Posen termasuk dalam mazhab yang menyatakan bahwa pandangan lama tentang "kebijakan moneter" sebagai penyelamat harus diubah dan diperlukan adanya pendekatan baru, jika ingin menangani penggelembungan harga aset secara tuntas.

Dari berbagai pendekatan yang ada, indeks harga perumahan dan suku bunga yang diberikan oleh Bank dari negara asal (home country) merupakan hal yang berguna untuk mempelajari terjadinya bubble. Akan tetapi, perlu dicatat bahwa diantara sektor-sektor lain pergerakan suku bunga pada pinjaman perumahan baik tetap atau mengambang selalu sinkron dengan suku bunga pasar uang jangka pendek pada tahun-tahun terakhir ini, sebagaimana terlihat dalam pengurangan suku bunga pada pinjaman perumahan. ${ }^{14}$

\section{Bidang Perhatian}

Terkait dengan perhatian terhadap PDB, suku bunga dan hubungannya dengan penggelembungan harga aset, ada beberapa pengamatan setelah menelaah kasus bencana bubble yang terjadi sebelumnya, yang menunjukkan bidang-bidang yang perlu dipahami dan diperhatikan, sebelum menentukan arah ekonomi di masa mendatang: ${ }^{15}$

(1) Goncangan (shock) suku bunga kebijakan adalah satu-satunya goncangan yang bisa berdampak jangka panjang terhadap suku bunga.

(2) Dalam jangka panjang kondisi kredit akan ditentukan oleh kondisi penawaran, yakni penawaran kredit agregat dan suku bunga.

(3) Pertumbuhan PDB dipengaruhi oleh goncangan (shock) permanen yang disebabkan oleh goncangan itu sendiri, suku bunga dan pertumbuhan kredit, dengan asumsi bahwa dalam tradisi monetaris, bahwa kemudahan ketersediaan kredit dengan suku bunga rendah memainkan peran penting dalam mendorong aktivitas ekonomi.

(4) Terakhir, harga perumahan dipengaruhi, dalam jangka panjang, oleh goncangan (shock) permanen dalam suku bunga, kredit dan goncangan PDB serta inovasi dalam harga perumahan.

\footnotetext{
14 Identifying Asset Price Bubbles in the Housing Market in India - Preliminary Evidence, Reserve Bank of India Occasional Papers, Vol. 27, No. 1 and 2, Summer and Monsoon 2006.

15 An In-Depth Analysis of the East Asian Crisis: Special Implications for India, Subhajit Sr., Indira Gandhi Institute of Development Research (IGIDR), 2008, accessible at http://papers.ssrn.com/sol3/papers.cfm?abstract_id=1152131.
} 


\section{Kebijakan Moneter}

Penemuan di atas menimbulkan kekhawatiran lain bagi kita tentang penggelembungan harga perumahan - Kebijakan moneter dan peran bank sentral dalam mengatasi masalah. Laporan IMF pada tahun $2003^{16}$ menyebutkan bahwa kenaikan harga perumahan pada akhir 1970an dan awal 1980an diikuti oleh pengetatan kebijakan moneter untuk mengurangi inflasi. Akan tetapi, beberapa tahun belakangan ini, kebergantungan pada kebijakan moneter juga dihadapkan pada berbagai kritik, dan diketahui bahwa faktor-faktor lain juga bertanggungjawab dalam penggelembungan harga aset dan hanya mengandalkan pengetatan kebijakan moneter tidak selalu menjadi solusi yang dapat dijalankan. Pandangan ini juga didukung oleh OECD, ${ }^{17}$ yang menyatakan bahwa, meskipun otoritas moneter memiliki banyak pilihan untuk merespon perkembangan harga aset termasuk harga perumahan, namun repon kebijakan terhadap harga perumahan harusnya hanya berkaitan dengan sejauh bahwa hal ini mengandung informasi tentang pertumbuhan dan inflasi output di masa mendatang, dan bahwa, jika diinginkan, akan lebih baik jika menggunakan instrumen kebijakan alternatif.

\section{Tren Pengambilan Risiko yang Berlebihan}

Meskipun peran kebijakan moneter telah banyak dipertimbangkan, beberapa pengamat melihat kehancuran (meltdown) yang mengancam pasar keuangan Barat sebagai biaya yang harus dibayar karena daya tarik yang menyesatkan dalam sistem keuangan, yang telah mendorong kecenderungan pengambilan risiko yang berlebihan. Nampaknya kekhawatiran timbul karena Bank dan lembaga keuangan berhasil menarik para kreditur dengan memberikan laba (return) yang tinggi karena tail risk yang lebih rendah dan pembayaran laba (return) berlebihan sebagai bonus, dan karenanya bisa menimbulkan berbagai krisis keuangan. Ini hanyalah pandangan satu dimensi dengan melihat pada spektrum mikro, sementara yang lain melacak masalah ke eksternalitas industri, dan mengklaim bahwa jika ekuitas bank naik seiring dengan harga aset, maka ukuran neraca konsisten dengan nilai yang berisiko juga akan naik, dan permintaan perantara keuangan (financial intermediary) akan bertindak mengikuti siklus (pro-cyclically). ${ }^{18}$

16 International Monetary Fund's report in World Economic Outlook, titled, "Growth and Institutions", published in April 2003, available at http://www.imf.org/external/pubs/ft/weo/2003/01/index.htm.

17 Asset Price Booms and Monetary Policy", Carsten Detken and Frank Smets, European Central Bank (ECB), 2004, accessible at: http://papers.ssrn.com/sol3/papers.cfm?abstract_id=533122.

18 Rethinking Capital Regulation", Kashyap, A.K., R. Rajan and J.C Stein, 2008. 


\section{Suku Bunga Rendah dan Sub Prime Loans}

Seperti negara-negara lain di dunia, India, sebelum adanya kesulitan ekonomi sekarang, telah menyaksikan era suku bunga yang rendah dan pertumbuhan ekonomi yang stabil, yang meskipun menarik perhatian konsumen, memastikan masa depan yang stabil bagi para investor, mendorong ekspansi neraca dari highly leveraged institution (HLI) namun juga menimbulkan kekhawatiran "sistem perbankan bayangan (shadow banking system)". Di negara-negara seperti AS, dimana fenomena semacam itu terlihat sangat kuat, 'sistem perbankan bayangan' berkembang pesat sehingga pada tahun 2006 "gabungan neraca bank-bank invetasi dan hedge fund mencapai lebih dari 50\% dari neraca bank komersial". ${ }^{19}$ Para ahli menyalahkan ekspansi ini akibat peningkatan basis ekuitas HLI dan juga memperingatkan adanya de-leveraging yang parah jika dan ketika harga aset turun, yang kemudian benar terjadi pada tahun 2008, maka bubble akan terjadi.

Diantara aset-aset yang diperoleh dalam lending boom ini adalah sub-prime mortgage beragunan yang dirancang untuk menjamin agar keluarga miskin bisa mendapatkan perumahan yang lebih murah dan terjangkau. Ide dasar sub-prime loan menyatakan bahwa bentuk dominan dari rumah tangga berpenghasilan rendah yang kaya adalah ekuitas rumah mereka. Jika peminjam bisa memberi pinjaman pada rumah tangga-rumah tangga ini untuk jangka pendek, katakanlah dua sampai tiga tahun, dengan suku bunga yang tinggi namun terjangkau, maka ekuitas akan terkumulasi dalam bentuk rumah. Selanjutnya mortgage bisa dibiayai kembali dengan rasio loan-to-ratio yang lebih rendah, yang mencerminkan apresiasi harga. Jadi, mortgage disusun sedemikian rupa sehingga pemberi pinjaman sub-prime secara efektif memiliki opsi (implisit) atas harga rumah. Setalah periode awal dua sampai tiga tahun, ada kenaikan suku bunga, sehingga peminjam pada dasarnya didorong untuk mendapatkan pembiayaan kembali dan pemberi pinjaman memiliki opsi untuk memberikan mortgage baru bergantung pada apresiasi nilai rumah tersebut.

Akan tetapi, kelemahan dasar yang tersembunyi di dalamnya dan yang diabaikan adalah bahwa dalam pembelian sekuritas yang disokong oleh sub-prime loan (yang disebut ABS), bank-bank bayangan mendapatkan aset dengan 'tail risk'. Selain itu, dengan harga rumah yang berada jauh di atas keseimbangan maka proses koreksi dalam harga rumah akan menghapus nilai opsi yang terdapat dalam ABS - menimbulkan kekhawatiran akan insolvensi dari bank tersebut. Ini kemudian ditambah dengan pandangan bahwa ledakan penggelembungan harga perumahan akan menciptakan krisis sistemik. ${ }^{20}$ Pasar modal

19 Liquidity and financial cycles", Adrian, Tobias and Hyun Song Shin, 2007, Mimeo Princeton University.

20 The Panic of 2007", Gary Gorton, 2008, Yale School of Management and NBER, Prepared for the Federal Reserve Bank of Kansas City, Jackson Hole Conference, August 2008, accessible at'http://www.kc.frb.org/publicat/sympos/2008/gorton.08.04.08.pdf. 
perumahan AS yang runtuh karena sub-prime mortage dan sub-prime loan pada dasarnya merupakan korban dari speculative bubble, dimana aset disimpan terutama karena keuntungan modal dan korban dari program yang dibuat untuk menentukan harga (pricing) mortgagebacked asset gagal mempertimbangkan kemungkinan penurunan harga perumahan.

\section{MENCOBA MENGATASI "MASALAH BUBBLE"}

Pasca September 2008, dunia menyaksikan kejatuhan beberapa pemain kunci pasar seperti Merrill Lynch dan Lehman Brothers, dan pemerintah terus berusaha menyelamatkan bankbank utama dengan rencana dana talangan (bail out) mereka yang populer. Sementara sebagian besar rencana bail out bertujuan untuk memberikan suntikan dana dalam jumlah besar ke dalam sistem keuangan, rencana darurat nasional pada dasarnya mencakup tiga aspek: Pertama, menurunkan gearing nasional, terutama karena leveraging akan menambah risiko, terutama jika dilakukan leverage dari pinjaman eksternal, karena semakin banyak yang Anda pinjam dari luar negeri semakin besar kerentanan Anda terhadap goncangan eksternal; Kedua, tingkat simpanan domestik yang lebih tinggi, yang tercermin dalam modal bank yang lebih tinggi dan rasio kredit/PDB yang lebih rendah, ketahanan terhadap kesulitan penyesuaian terhadap goncangan eksternal dan internal haruslah lebih besar dan Ketiga, tanpa memandang rezim nilai tukar, harus ada komitmen terhadap mata uang yang stabil, yang berarti cadangan eksternal yang lebih kuat, inflasi yang rendah dan sistem perbankan yang sehat.

Poin-poin di atas pada dasarnya muncul dari panduan yang diberikan setelah terjadinya Krisis Keuangan Asia, yang mencakup:21

- Kebijakan yang kredibel, dimana kebijakan moneter dan fiskal konsisten satu sama lain, baik dalam hal kebijakan maupun penerapan.

- Liberalisasi akun modal secara bertahap.

- Fundamental yang sehat yang mencakup suku bunga simpanan domestik yang tinggi, posisi fiskal dan neraca pembayaran yang berkesimbambungan, cadangan devisa yang tinggi serta sistem manajemen utang yang hati-hati (prudent).

- Pengawasan yang baik mencakup adanya kecukupan modal dan kebutuhan likuiditas yang solid bagi sektor keuangan, serta pemeriksaan dan pengawasan rutin atas lembaga keuangan dan pasar. Sistem perbankan yang sehat yang memiliki kemampuan untuk menghindari konsentrasi dan risiko kredit yang berlebihan serta kemampuan untuk mengelola risiko pasar.

21 Bank Restructuring: Lessons from the 1980s", Sheng, Andrew, Washington, D.C.: World Bank, 1996. 
- Infrastruktur keuangan yang kuat yang mencakup sistem pembayaran dan penyelesaian yang efisien untuk transaksi domestik dan internasional. Pada dasarnya, untuk mengurangi risiko pembayaran dan memungkinkan bank sentral untuk mengawasi aliran mata uang domestik serta eksposur bank secara real time.

- Struktur insentif yang tidak menyesatkan, seperti hambatan perpajakan dan regulasi yang tidak mendorong konsentrasi risiko atau leverage berlebihan dalam sektor ekonomi apapun.

Sementara dunia berdebat tentang cara-cara untuk menghindari jebakan bubble, beberapa alternatif lain dipaparkan untuk mengatasi sindrom kejatuhan global saat ini.

\section{Debt Equity Swap}

Restrukturisasi modal seringkali mencakup debt-equity swap, dimana kreditur menjadi pemilik dan melepaskan peminjam dari persyaratan agunan dan kewajiban membayar bunga. ${ }^{22}$ Secara sederhana, pemegang ekuitas yang lama dihapus dan klaim utang lama diubah menjadi klaim ekuitas dalam entitas baru yang terus beroperasi dengan struktur modal baru. Alternatif yang lain, pemilik utang juga setuju untuk memotong nilai nominal (face value) utang, sebagai ganti atas beberapa jaminan (warrant). Hal ini juga ada dalam siklus kredit yang dikembangkan oleh Kiyotaki dan Moore, yang awalnya dirancang untuk menunjukkan bahwa goncangan riil ( real shock) memiliki dampak menetap pada ekonomi daripada apa yang biasanya diperkirakan dan dipertimbangkan tentang bagaimana utang harus diberi agunan karena bahaya moral, dan agunan (dumping collateral) menimbulkan eksternalitas negatif yang signifikan. ${ }^{23}$

\section{Suntikan Modal}

Fitur kunci dari rencana penyelamatan Inggris adalah penyediaan suntikan modal (sukarela) dalam bentuk saham preferensi atau utang tanpa agunan. Ini terutama ditujukan untuk mengatasi kesulitan keuangan dengan memeriksa proses de-leveraging yang terjadi setelah goncangan menjadi nilai bersih, dan sehingga membatasi eksternalitas negatif dari penjualan aset, dan disaat yang sama memastikan terhindarnya ancaman solvensi akibat penjualan besarbesaran (fire-sales) aset agunan.

22 Why Paulson is wrong": Economists Voice, Zingales, Luigi, 2008, The Berkeley Electronic Press.

23 Credit Cycles", Kiyotaki, Nobuhiro, and John Moore, Journal of Political Economy, 105, 1997. 


\section{Penurunan Nilai Pinjaman}

Penurunan nilai pinjaman (loan write-down) adalah cara lain untuk menghindari eksternalitas negatif yang ditimbulkan oleh program penegakan pinjaman (loan enforcement). Pemerintah bisa mengeluarkan kebijakan bagi Bank atau Lembaga Keuangan dimana reformasi kebangkrutan yang diajukan memungkinkan pemilik rumah untuk menurunkan nilai rumah mereka dan tetap tinggal di rumah mereka. [Selain itu], pemerintah bisa menanggung sebagian mortgage, dengan memanfaatkan suku bunga yang lebih rendah yang mana pemerintah memiliki akses pendanaan dan memiliki kemampuan yang lebih besar untuk meminta pembayaran kembali. Sebagai ganti atas suku bunga yang lebih rendah - yang menjadikan perumahan menjadi lebih terjangkau - pemerintah bisa meminta pemilik rumah untuk mengkonversi pinjaman menjadi pinjaman terjamin (recourse loan) (mengurangi kemungkinan default), meminta pemegang mortgage awal untuk menurunkan nilai mortgage menjadi katakanlah $90 \%$ dari harga pasar saat itu. ${ }^{24}$

\section{PERDEBATAN BESAR TENTANG KEBIJAKAN MONETER}

Meskipun telah ada berbagai alternatif untuk mengatasi "bencana penggelembungan", namun perdebatan utama masih berkutat tentang apakah Kebijakan Moneter memainkan peran yang paling penting dalam menentukan/mengatasi volatilitas dan pembentukan gelembung harga aset? Harus dipahami bahwa restrukturisasi hukum bukanlah satu-satunya hal yang bisa memperbaiki kondisi mereka yang telah melakukan pinjaman dengan aset yangnovervalued yang harganya 'terkoreksi'. Penyesuaian suku bunga secara tepat waktu juga bisa membantu memperbaiki hal ini. Pemikirannya cukup sederhana - untuk menstabilkan harga aset-aset yang kejatuhan nilainya mengancam sistem. Pemotongan suku bunga riil pada saat terjadi bubble dan setelahnya akan menyebabkan pengalihan dari kreditur ke peminjam, dan membantu membatasi fire-sales di masa krisis.

Akan tetapi, analisa saat ini jauh lebih kompleks daripada kelihatannya karena para ekonom terbelah dalam hal peran Kebijakan Moneter dalam menentukan penggelembungan harga aset.

Dikatakan bahwa peran Bank Sentral adalah untuk mengelola inflasi dan Bank melakukannya melalui Kebijakan Moneter. Meskipun negara-negara di dunia sangat terbantu dengan fokus Bank Sentral pada inflasi, namun ada beberapa keheranan karena Philips Curve,

24 We aren't done yet: Comments on the financial crises and Bailout", Stiglitz, Joseph E, 2008, Economists' Voice: The Berkeley Electronic Press, (October). 
melakukan pertukaran (trade-off) antara inflasi dan pengangguran yang kemudian melemahkan peran inflasi. Akan tetapi, argumen-argumen ini terbantahkan oleh Milton Friedman pada tahun 1970 di Asosiasi Ekonomi Amerika dimana dia menunjukkan bahwa tidak ada trade-off antara inflasi dan pengangguran. Inflasi dimanapun juga selalu menjadi fenomena moneter dan ilmu ekonomi moneter tidak pernah melihat ke belakang lagi sejak saat itu.

Meskipun merupakan regulator terpisah, Bank Sentral terus menjadi bagian penting dari pasar keuangan. Bank Sentral mengatur uang beredar melalui Bank-Bank yang kemudian menjadi bagian tak terpisahkan dari sistem keuangan. Karenanya, pengawasan sistem keuangan otomatis menjadi tanggung jawab dari Bank Sentral, yang juga berperan sebagai regulator dari berbagai jenis pasar keuangan - pasar utang, pasar mata uang, dll. Sebagian besar Bank Sentral mengeluarkan gambaran (outlook) pasar keuangan serta gambaran ekonomi. Gambaran ini memberi sejumlah informasi tentang perkembangan pasar keuangan bagi para pelaku pasar keuangan.

Selain itu, di negara-negara seperti India, dimana Bank Sentral (Reserve Bank of India) meningkatkan rasio cadangan kas Bank, karena mengkhawatirkan inflasi yang terus tumbuh, terutama tentang tingginya harga-harga aset seperti saham dan tanah, menyebabkan para ekonom berpikir apakah layak bagi bank sentral untuk mengasumsikan telah terjadi bubble dan melakukan tindakan untuk meledakkannya (prick)? Ini kemudian membuka kembali perdebatan besar tentang peran Bank Sentral dalam menentukan statistik keuangan suatu negara.

Ahli ekonomi di seluruh dunia, terbelah dalam masalah ini dan ini terlihat jelas dari penelitian yang dilakukan Nouriel Roubini dari Roubini Economics, ${ }^{25}$ yang mengatakan bahwa Bank Sentral harus meledakkan (prick) bubble, dibandingkan dengan pandangan Adam S. Posen, senior fellow di Institute of International Economics, yang berpandangan bahwa Bank Sentral tidak boleh melakukan hal tersebut, karena bubble bisa disebabkan oleh banyak faktor dan bukan hanya karena faktor moneter.

(Beberapa) argumen Roubini didasarkan pada pandangan bahwa bank sentral harus mencegah terjadinya bubble dan bukan hanya bereaksi setelah bubble terjadi demi membatasi kerusakan. Dia mengatakan bahwa teori ekonomi "mendukung pandangan untuk mentargetkan harga aset dan penggelembungan aset", dan tidak ada yang benar-benar tahu apakah bubble benar terjadi atau tidak. Ketidakpastian ini bukanlah alasan yang memadai bagi bank sentral untuk bertindak. Masalah yang sebenarnya adalah apakah aturan kebijakan moneter yang optimal harus bergantung pada tingkat ketidakpastian. Jadi "meskipun jika otoritas moneter 
tidak bisa dengan pasti memisahkan dua komponen harga aset - yang satu didasarkan pada fundamental dan satu lagi tidak - respon kebijakan yang optimal mengindikasikan reaksi terhadap seluruh harga aset (dibandingkan reaksi terpisah terhadap komponen fundamental dan non-fundamental)." - Pandangan inilah yang pada dasarnya diambil oleh Reserve Bank of India.

Di sisi lain, Posen memiliki pandangan yang bertentangan, dengan mengatakan bahwa "Bank sentral tidak boleh berurusan dengan masalah mencoba meledakkan (prick) penggelembungan harga aset karena hubungan antara kondisi moneter dan meningkatnya bubble sangat lemah". Karenanya, jika bank sentral menggunakan taktik yang biasa mereka gunakan, seperti menaikkan suku bunga atau mengurangi jumlah yang tersedia bagi bank untuk memberikan pinjaman, maka bank sentral hanya akan menyebabkan resesi. "Analisa biaya-keuntungan", kata Posen, "tidak membenarkan tindakan preemptive semacam itu".

Akan tetapi meskipun memastikan bahwa tidak ada pengganti moneter untuk stabilitas keuangan dan tidak ada pengganti pasar untuk kemudahan moneter pada saat credit crunch yang parah, asumsi dasar yang diambil oleh Posen adalah adanya sistem pengawasan perbankan yang baik, karena jika sistem keuangan rentan, bank sentral bisa menyebabkan ekonomi berada dalam kesulitan jika tidak bertindak cepat. Nampaknya di India, Reserve Bank mengambil pandangan keberatan ini untuk mempertahankan pendiriannya dan dengan menekankan pada fakta bahwa sistem perbankan yang ada sekarang tidaklah kuat, karenanya intervensi mereka sangat dibutuhkan. Namun demikian, kami merasa bahwa pembelaan tersebut tidak memadai untuk membenarkan intervensi Bank Sentral dalam menentukan kebijakan moneter yang mencoba mengatasi penggelembungan harga aset pada saat awal, yakni sebagai tindakan preemptive.

Krisis sub-prime dan harga minyak/komoditas baru-baru ini memunculkan pandangan bahwa kebijakan moneter yang longgar juga berkontribusi menyebabkan kenaikan harga aset. Meningkatnya permintaan akan perumahan menyebabkan naiknya harga dan menyebabkan naiknya kekayaan. Ini menyebabkan kenaikan konsumsi dan terlihat bahwa sebagian dari pendapatan (proceeding) juga diinvestasikan di pasar ekuitas/komoditas. Ini menyebabkan kenaikan harga ekuitas. Alternatif lainnya, masyarakat bisa berinvestasi langsung di pasar ekuitas dan komoditas dengan mengambil pinjaman dengan suku bunga rendah yang memicu kenaikan harga aset dan kemudian menginvestasikan pendapatan (proceed) di pasar perumahan. Saat siklus suku bunga mengalami perubahan, koreksi segera terasa di seluruh pasar aset. Akan tetapi, sampai krisis yang terjadi baru-baru ini Bank Sentral belum benar-benar memberi perhatian, karena krisis yang terjadi masih kecil namun krisis sub-prime adalah waktu untuk mengkaji kembali kebijakan. Teori "perlunya menargetkan harga aset" juga menyiratkan bahwa 
tidaklah penting untuk mengetahui dengan tepat ukuran bubble selama penggelembungan harga bisa diidentifikasi. Sebagian besar pejabat Bank Sentral dalam pidato-pidato mereka menyatakan kekhawatiran tentang menaikkan harga perumahan sementara penelitian telah menunjukkan bahwa Bank Sentral secara implisit menargetkan harga aset. Selain itu, Bank Sentral berada dalam posisi terbaik dalam ekonomi untuk menaksir perkembangan kenaikan harga aset yang tidak rasional.

Ada mazhab lain yang merasa bahwa Posen memang benar dalam memperlihatkan bahwa bank sentral tidak boleh langsung mempertimbangkan harga aset dalam pembuatan kebijakan moneter namun mempertimbangkan laissez-faire dalam pendekatannya sembari merespon pergerakan tajam inflasi dan output bahkan jika pergerakan (swing) harga aset merupakan sumbernya. Dalam konteks ini harus dipahami pula bahwa, penggelembungan harga juga timbul dari faktor fundamemtal lain yang mungkin tidak dipertimbangkan oleh Bank Sentral dan kebijakannya. Salah satu fundamental tersebut, sebagaimana dinyatakan oleh Marcus Brunnermeier, adalah bahwa ada perspektif perilaku dalam perkembangan gelembung (bubble) aset, yang mungkin tidak dipahami oleh kebijakan moneter dan karenanya, kebijakan tersebut tidak menyelesaikan masalah penggelembungan harga secara realistis. ${ }^{26}$ Disamping itu, ada pula kekhawatiran bahwa identifikasi Bank Sentral atas bubble bisa menyebabkan kerusakan yang lebih parah daripada yang diperkirakan dan karenanya, jika Bank Sentral menaikkan suku bunga untuk melawan asset bubble maka akan bisa melemahkan seluruh aktivitas ekonomi, dan dengan demikian menganggap kebijakan moneter hanya sebagai alat untuk menargetkan penggelembungan harga aset.

Analisa di atas menunjukkan bahwa kaitan antara harga aset dan kebijakan moneter sudah dipahami dengan baik namun tidak ada cara untuk menanganinya. Ini bukan berarti bahwa Bank sentral bisa mengabaikan masalah ini karena baik pendalaman sektor keuangan (financial deepening) maupun inovasi keuangan hanya akan memperburuk masalah. Sampai terjadinya krisis sub-prime, lembaga-lembaga terkemuka dalam artikel penelitiannya menyatakan bahwa Bank Sentral tidak boleh menargetkan harga aset karena sebagian besar krisis terjadi di negara-negara berkembang. Masalah yang diidentifikasi adalah - sistem keuangan yang lemah, kebijakan makroekonomi yang buruk, dll. Sekarang, dimana krisis dimulai di AS dan melanda negara-negara berkembang lain maka alasan ini tidak valid. IMF dalam World Economic Outlook (April 2008) mengeluarkan laporan yang menganalisa pasar Perumahan dan Kebijakan Moneter. $^{27}$

26 Synchronization risk and delayed arbitrage", Abreu, Dilip and Markus K. Brunnermeier,2002,Journal of Financial Economics, Vol. 66(2-3), pp. 341-360.; Also See "Bubbles and Crashes",Abreu, Dilip and Markus K. Brunnermeier, 2003, Econometrica, Vol. 71(1), pp. 173-204.

27 Review of Annual Statement on Monetary Policy for the Year 2006-07, Reserve Bank of India, 2006. 
Tujuan utama bab ini adalah untuk menelaah bagaimana inovasi dalam sistem keuangan perumahan di negara-negara ekonomi maju dalam dua dekade terakhir telah mengubah peran sektor perumahan dalam siklus usaha dan mekanisme penyampaian kebijakan moneter. Disimpulkan bahwa perubahan-perubahan ini telah memperlebar spillover dari sektor perumahan ke seluruh perekonomian dan telah menambah dampaknya dengan memperkuat peran perumahan sebagai agunan. Analisa ini menyatakan bahwa di negara dengan pasar mortgage yang lebih maju, pembuat kebijakan moneter mungkin perlu merespon dengan lebih agresif terhadap perkembangan sektor perumahan, dalam pendekatan manajemen risiko yang menganggap dinamina harga perumahan sebagai salah satu faktor kunci yang harus dipertimbangkan dalam mengkaji keseimbangan risiko pada output dan inflasi.

Hal ini telah menimbulkan kontroversi karena masyarakat merasa bahwa IMF menganjurkan teori bahwa Bank Sentral harus menargetkan harga aset. Seorang Chief Economist IMF mengklarifikasi:28

"Kebijakan moneter mungkin perlu merespon inflasi harga perumahan terutama di negaranegara dimana rumah tangga lebih mudah mengakses kredit mortgage. Ini sesuai dengan pendekatan "manajemen risiko" luas dalam kebijakan moneter yang mengakui semua ketidakpastian dalam berbagai goncangan yang melanda negara. Logikanya adalah bahwa kebijakan moneter mungkin perlu merespon inflasi harga perumahan terutama jika harga perumahan bergerak dengan cepat atau keluar dari kisaran valuasi normal.

Namun sayangnya laporan ini tidak menawarkan ide konstruktif tentang bagaimana Bank Sentral harus menargetkan harga aset, namun demikian ini tetap merupakan suatu perubahan pendirian. Akan tetapi, kami merasa bahwa meskipun saran tersebut sangat menarik, namun analisa yang lebih mendalam akan memperlihatkan adanya kelemahan di dalamnya yang akan menyulitkan dalam implementasinya:

a) Memasukkan Harga Aset dalam Indeks Inflasi: Ini adalah usulan yang paling radikal namun memiliki banyak keterbatasan. Pertama, adalah sulit untuk mengidentifikasi aset yang akan dimasukkan. Kedua, harga aset bergerak secara acak yang menjadikan tugas untuk menaksir inflasi menjadi lebih sulit lagi.

b) Meledakkan (prick) Bubble: Bank sentral harus secara agresif menaikkan suku bunga untuk melawan kenaikan harga aset. Akan tetapi, pertama-tama adalah sulit untuk mengidentifikasi bubble dan beberapa aset mungkin sudah memiliki harga yang memadai. Kedua, tidak ada hubungan yang sangat jelas antara suku bunga dan harga aset dan kenaikan suku bunga

28 Housing and Business Cycle", World Economic Outlook, 2008 International Monetary Fund, accesible at http://uww.imf.org/external/ pubs/ft/weo/2008/01/index.htm. 
yang tinggi mungkin diperlukan untuk menenangkan harga aset yang bisa menjadikan ekonomi dalam keadaan tertekan.

c) Bersandar pada the Wind Act: Pendekatan ini makin banyak diterima di bidang kebijakan. Secara sederhana ini berarti bahwa bank sentral mengadopsi pandangan keras (hawkish) terhadap kenaikan harga aset sejak awal. Ini akan menghilangkan pandangan bahwa bank sentral hanya akan bertindak pada waktu kesulitan (distress). Namun tidak ada banyak pandangan tentang bagaimana pendekatan ini bisa dijalankan. Beberapa ekonom menyarankan pembatasan kredit (persyaratan modal yang lebih tinggi, dll) pada saat boom dan mengurangi pembatasan kredit pada saat resesi. Beberapa ekonom lain menganjurkan bahwa harus ada persyaratan marjin yang lebih tinggi pada saat boom. Pandangan yang lain adalah Bank Sentral mengelola perkiraan inflasi dengan mengkomunikasikan pada masyarakat bahwa mereka bisa mengelola ekspektasi harga aset.

Seiring dengan tindakan Bank Sentral di seluruh dunia yang mencoba mengatasi keterbatasan dan mencoba dan melakukan implementasi Panduan di atas, Reserve Bank of India dalam laporan kebijakan moneter tahunan untuk tahun 2006-07 menyatakan bahwa:29

Nampaknya secara global dan juga di India, kondisi inflasi mungkin tidak secara tepat tercermin dalam harga yang dihadapi konsumen dan ketidakseimbangan pembiayaan meningkat dengan adanya banyak likuiditas, kenaikan harga aset dan kenaikan minat terhadap risiko. Dalam konteks inilah, dan sejalan dengan berbagai pendekatan indikator yang digunakan oleh Reserve Bank, bahwa kebijakan moneter di India secara konsisten menekankan perlunya kewaspadaan terhadap indikasi kenaikan permintaan agregat dalam konsumen dan kepercayaan usaha, harga aset, kinerja perusahaan, dan pertumbuhan dana cadangan dan uang beredar, kenaikan perdagangan dan defisit current account dan, khususnya, kualitas pertumbuhan kredit.

Melihat kembali ke belakang, pendekatan sensitif risiko ini telah sangat membantu dalam mengekang tekanan permintaan agregat dan dampak ronde kedua. Dipastikan juga bahwa selalu ada kewaspadaan terhadap ancaman pada stabilitas keuangan melalui periode saat inflasi naik dan harga aset, terutama dalam perumahan dan real estate, muncul sebagai tantangan bagi otoritas moneter di seluruh dunia.

Disamping kekhawatiran tentang harga aset, RBI juga meminta bank untuk menaikkan persyaratan provisi pinjaman ke sektor-sektor spesifik seperti eksposur pasar modal, pinjaman perumahan dan real estate komersial. RBI telah menaikkan bobot risiko dalam eksposur bank

29 Housing and Business Cycle", World Economic Outlook, 2008 International Monetary Fund, accesible at http://www.imf.org/external/ pubs/ft/weo/2008/01/index.htm. 
terhadap real estate komersial. Meskipun beberapa ekonom merasa bahwa pendekatan terpandu (guarded approach) yang diambil RBI ini telah mencegah India agar tidak terlalu terpengaruh oleh krisis keuangan namun para penentangnya merasa bahwa ini adalah analogi yang salah yang digunakan oleh RBI untuk memperkuat intervensinya yang dalam jangka panjang akan terbukti tidak bermanfaat.

Akan tetapi, dengan krisis yang tengah melanda saat ini, nampaknya ada konsensus umum di India, terkait dengan perlunya intervensi cepat dari Reserve Bank untuk mencegah bencana lain. Namun demikian, pertanyaan yang masih diperdebatkan adalah - apakah peran yang tepat dari kebijakan moneter dalam peristiwa penggelembungan harga aset (asset price bubble)? Metode apa yang harus diadopsi untuk mencapai tujuan kebijakan moneter? Salah satu pandangan adalah bahwa kebijakan moneter harus melakukan lebih dari sekedar hanya mengikuti standar target inflasi. Para penganjur pandangan ini mengakui bahwa kenaikan harga aset seringkali memiliki dampak ekspansioner terhadap ekonomi, dan terkadang menjadi sinyal adanya tekanan inflasi, sehingga pengetatan kebijakan moneter merupakan tindakan yang tepat. Namun menurut pandangan ini, kebijakan hanya boleh merespon perubahan yang diamati dalam harga aset sejauh bahwa hal tersebut menyiratkan perubahan saat ini atau masa mendatang terhadap inflasi atau kesenjangan output. Namun tetap saja "Kita tidak boleh menggunakan kebijakan terlalu lembut terhadap penggelembungan harga aset yang sedang berkembang, atau terlalu agresif, dan mencoba untuk meledakkannya." ${ }^{30}$

Tetapi, pandangan alternatif yang menantang pendapat di atas dan percaya bahwa kebijakan moneter harus melakukan lebih dari sekedar merespon perkembangan aktual dan perkembangan yang diperkirakan dalam inflasi dan kesenjangan output, telah membuat penulis mempertimbangkan argumen bahwa: "Menaikkan suku bunga saat harga aset naik di atas ambang batas, dan menurunkan suku bunga saat harga aset jatuh di bawah ambang batas, cenderung akan mengimbangi dampak pada output dan inflasi penggelembungan [harga aset], dan karenanya akan meningkatkan keseluruhan stabilitas makroekonomi.31

Hal ini mengarahkan pada kesimpulan bahwa meskipun perdebatan tentang peran kebijakan moneter dalam mengkaji penggelembungan harga aset adalah suatu pertanyaan yang akan selalu ada, namun kondisi dunia saat ini mengharuskan adanya perubahan outlook, dimana kita perlu keluar dari belenggu perspektif ortodoks dan mencoba memikirkan landasaan baru yang terbukti efektif dalam mengatasi masalah ini.

30 Monetary Policy and Asset Price Volatility, Bernanke, Ben, and Mark Gertler, 1999, In New Challenges for Monetary Policy: A Symposium Sponsored by the Federal Reserve Bank of Kansas City: 77-128. Federal Reserve Bank of Kansas City.

31 Asset Prices and Central Bank Policy", Cecchetti, Stephen G., Hans Genberg, John Lipsky, and Sushil Wadhwani,2003, Journal of Money, Credit and Banking. 
Kami merasa bahwa undang-undang anti penggelembungan (anti bubble law) di negaranegara berkembang seperti India, perlu diletakkan dalam template, yang dipetakan dalam penelitian mikroekonomi (termasuk keuangan behavioral) dan makroekonomi tentang pembentukan gelembung dan mencakup:

(1) Undang-undang yang bertujuan untuk menyediakan informasi bagi investor tentang nilai dasar aset, pada dasarnya mencakup undang-undang yang mewajibkan pengungkapan (disclosure) yang lebih luas dan pendidikan investor baik untuk memfokuskan perhatian investor pada informasi tentang nilai fundamental dan bukannya pada noise atau untuk memperbaiki informasi asimetris yang menyebabkan penentuan harga aset yang salah;

(2) Undang-undang yang bertujuan untuk memotong feedback loop positif, dan karenanya bertujuan untuk memperkecil feedback positif yang tercipta saat para investor mengejar kenaikan harga aset dan termasuk perpajakan transaksi, circuit breaker dan undang-undang yang membatasi akses investor ke pasar tertentu atau menyalurkan investor yang lemah (less sophisticated) ke aset yang tidak terlalu berisiko;

(3) Menghapus batasan hukum arbitrase;

(4) Undang-undang yang membatasi kredit kepada investor untuk mengatasi spekulasi (mis. regulasi marjin).

\section{JALAN KE DEPAN - PENDEKATAN REGULASI}

Sebagaimana disarankan di atas, kami merasa bahwa mengadaptasi pandangan apapun terkait dengan relevansi kebijakan moneter dalam mengatasi penggelembungan harga aset merupakan hal yang tidak tepat. Kondisi saat ini gagal memahami bahwa ada pendekatan lain yang bisa menjadi alat efektif untuk menyelesaikan masalah instan yang ada.

Meskipun cara-cara yang dianjurkan di atas pada dasarnya adalah cara-cara alternatif, yang kami rasa bisa memberi kelonggaran dalam skenario saat ini namun kami juga harus memahami bahwa perubahan-perubahan tersebut tidak bisa dilakukan tanpa adanya perubahan besar dalam kebijakan Bank/Lembaga Keuangan. Meskipun ada banyak penelitian yang difokuskan pada pertanyaan tentang apakah kebijakan moneter pre-emptive seharusnya digunakan atau tidak untuk mempengaruhi harga aset, namun hanya ada sedikit penelitian yang membahas efektifitas, keinginan (desirability) dan sifat kebijakan regulasi pre-emptive dalam konteks ini. ${ }^{32}$

32 Asset Price Bubbles and Prudential Regulation", Working Paper 3, September 2001, Australian Prudential Regulation Authority, accessible at http://www.apra.gov.au/Policy/upload/Asset-Price-Bubbles-and-Prudential-Regulation-Sep2001.pdf. 
Kami mendasarkan pandangan kami atas tiga proposisi utama berikut ini, yakni:

(i) Kebijakan moneter tidak tepat atau relatif tidak efektif dalam meledakkan penggelembungan;

(ii) Pro-cylicality sistem keuangan bisa dikurangi dengan kebijakan regulasi yang tepat; dan

(iii) Sistem perbankan yang kuat yang dengan tepat mengukur dan menilai risiko bisa mengurangi kemungkinan berkembangnya penggelembungan harga aset.

Bisa dipahami bahwa harga aset memang jatuh tajam dari waktu ke waktu dan bahwa kejatuhan ini menimbulkan gangguan ekonomi yang parah; tanpa memandang apakah kejatuhan ini hanya berupa pergerakan harga yang berlebihan ataukah memang suatu penggelembungan (bubble). Namun fokus utamanya adalah pada hubungan antara pergerakan harga dan perilaku bank dimana regulasi kehati-hatian (prudent regulation) bisa mempengaruhi hubungan tersebut. Berikut adalah bukti-bukti untuk melengkapi teori tersebut:

- Penggelembungan (bubble) bisa merusak ekonomi riil;

- Ada hubungan antara pembentukan/peledakan bubble dan perilaku bank; dan

Regulasi bisa mempengaruhi perilaku tanpa efek samping material; baik untuk ekonomi - atau untuk tujuan regulasi kehati-hatian (prudent regulation) lainnya.

Kindleberger, ${ }^{33}$ pada tahun 1989 telah menyatakan bahwa penggelembungan harga aset seringkali, meski tidak selalu, terkait dengan krisis perbankan dan biasanya dipicu oleh ekspansi moneter dan temuannya ini didukung oleh bukti empiris bahwa kegagalan bank berbanding terbalik dengan siklus usaha. Pandangan ini kemudian diperkuat oleh Allen dan Gale $^{34}$ yang menyatakan bahwa adanya biaya lembaga dalam sektor perbankan, beserta ketidakpastian tentang ekspansi kredit masa mendatang, menentukan tingkat penggelembungan harga aset dan dampaknya pada ekonomi riil.

Dengan memperhatikan hal-hal di atas, para ekonom menentang penggunaan kebijakan moneter untuk mengendalikan atau meledakkan bubble, dan ekonom seperti Bernanke dan Gertler (1999), melalui model "Dynamic New Keynesian", menunjukkan bahwa kebijakan moneter tidak seharusnya merespon perubahan harga aset, kecuali jika harga aset menyiratkan adanya perubahan ekspektasi inflasi. ${ }^{35}$ Peledakan gelembung harga aset yang tidak berimplikasi pada ekspektasi inflasi sangat ditentang oleh model Bernanke dan Gertler. Dengan menggunakan model "Dynamic New Keynesian" yang dibatasi agunan, Bordo dan Jeanne (2001) menunjukkan bahwa, jika terjadi penurunan harga aset secara tiba-tiba, kebijakan moneter tidak efektif

33 Anatomy of a Typical Financial Crisis", Charles Kindleberger, 1989, accessible athttp://delong.typepad.com/egregious_moderation/ 2009/01/charles-kindleberger-anatomy-of-a-typical-financial-crisis.html.

34 Financial Contagion", Franklin Allen and Douglas Gale, The Journal of Political Economy, Vol. 108, No. 1. (Feb., 2000), accessible at http://links.jstor.org/sici?sici=0022-3808\%28200002\%29108\%3A1\%3C 1\%3AFC\%3E2.0.CO\%3B2-D.

35 Monetary Policy and Asset Price Volatility, Bernanke, Ben, and Mark Gertler, 1999, In New Challenges for Monetary Policy: A Symposium Sponsored by the Federal Reserve Bank of Kansas City: 77-128. Federal Reserve Bank of Kansas City. 
dalam meningkatkan output dan, selain itu, penggunaan kebijakan moneter secara pre-emptive cenderung tidak akan efektif dalam menghindari krisis pasar (market crash). ${ }^{36}$ Lebih lanjut, Kaufman (1998) juga menentang penggunaan kebijakan moneter untuk meledakkan bubble dan Schwartz (2001) menyatakan bahwa kebijakan moneter bukan hanya tidak efektif namun juga tidak tepat untuk meledakkan bubble, dengan alasan bahwa, kecuali jika bubble diakibatkan oleh kondisi moneter yang lemah, harga pasar akan mengkoreksi sendiri berdasarkan pada proyeksi pertumbuhan pendapatan. ${ }^{37}$

Meskipun ada pendapat berbeda dari para ekonom seperti Kent dan Lowe (1997), teori yang muncul kemudian (termasuk teori Kent dan Lowe) telah menegaskan penggunaan regulasi kehati-hatian (prudent regulation) untuk merespon bubble, ${ }^{38}$ yakni:

- Borio et al menyatakan bahwa salah satu keuntungan menggunakan regulasi kehati-hatian (prudent regulation) untuk merespon penggelembungan harga aset adalah bahwa biaya pilihan kebijakan regulasi yang buruk cenderung lebih kecil dibandingkan biaya pilihan kebijakan moneter yang buruk; mereka juga menyatakan bahwa dampak perubahan kebijakan regulasi lebih bisa diprediksi.

- Bordo dan Jeanne menyatakan bahwa persyaratan modal dan asuransi deposito berbasis risiko harus digunakan untuk mengimbangi kerugian modal akibat kejatuhan harga aset secara tiba-tiba, meskipun argumen mereka lebih condong pada regulasi (dan kebijakan fiskal) yang lebih didasarkan pada bukti ketidakefektifan kebijakan moneter, dan bukannya pada bukti efektifitas regulasi.

- Kent dan Lowe menyatakan bahwa regulasi kehati-hatian (prudent regulation) bisa mendukung kebijakan moneter dengan meminimalkan dampak negatif penggelembungan harga aset terhadap sistem keuangan yang, kemudian, menjamin bahwa sistem perbankan sehat dan tidak mengalami overexposed pada risiko-risiko terkait dengan peledakan bubble.

Namun demikian, bagaimana cara menggunakan alat prudentia/ untuk mengatasi bubble adalah pertanyaan yang masih belum terjawab. Para pengawas mengkaji dan mempengaruhi pengambilan risiko di lembaga keuangan melalui berbagai metode kualitatif dan kuantitatif. Teknik ini meliputi pembatasan pada komposisi portofolio, persyaratan modal berbasis risiko, loan loss provisioning, dan stress test atas eksposur risiko pasar. Meskipun, para penganjur di seluruh dunia merasa bahwa kebijakan regulasi adalah cara paling efektif untuk mengatasi penggelembungan harga aset, kami merasa bahwa ada kelemahan laten yang bisa melemahkan

36 Asset Price, Reversals, Economic Instability, and Monetary Policy", Bordo, M.D. and O. Jeanne, (2001), Paper presented at the Annual Meeting of the American Financial Association, New Orleans, January 7, 2001.

37 Asset Price Inflation and Monetary Policy",Schwartz, A. J.,(2001),Paper presented at the Annual Meeting of the American Financial Association, New Orleans, 7 January.

38 Asset Price Bubbles and Monetary Policy',Kent, C. and P. Lowe, 1997, Reserve Bank of Australia, Research Discussion Paper 9709. 
dasar usulan ini dan karenanya menjadikan usulan ini tidak efektif, terutama di negara-negara berkembang seperti India. Oleh sebab itu, agar kebijakan tersebut bisa diimplementasikan dengan efektif, kelemahan-kelemahan berikut harus diatasi dengan cepat.

(i) Pembatasan Komposisi Portofolio: Pembatasan portofolio secara historis telah digunakan sebagai alat untuk pengawasan bank dan juga kebijakan moneter. Untuk membatasi risiko penggelembungan harga aset, Schwartz (2001) menyarankan agar regulasi terutama berfokus pada komposisi portofolio bank dan memberikan insensif bagi lembaga keuangan untuk melakukan self-regulation dengan mengkaitkan premi asuransi deposito dengan benchmark portofolio aset, dimana bobot pinjaman yang dijamin oleh tiap kelas ditentukan oleh regulator. Argumen untuk mempengaruhi komposisi portofolio didasarkan pada pengalaman AS pada tahun 1920an dan pengalaman Jepang pada tahun 1980an. Pada kedua periode tersebut, perubahan kredit bank ke arah pendanaan investasi spekulatif di pasar ekuitas dan properti telah memfasilitasi boom harga aset dan menjadikan sistem keuangan mereka berada dalam posisi lemah saat periode boom ini berakhir.

\section{Kelemahan:}

- Pembentukan seperangkat pembobotan (weight) untuk benchmark portofolio adalah hal yang problematis.

- Mengganti penilaian regulator dengan penilaian manajemen bank - sesuatu yang bertentangan dengan filosofi berbasis risiko yang mulai tumbuh dalam regulasi perbankan dalam beberapa dekade terakhir.

- Industri dengan pertumbuhan pesat cenderung memiliki permintaan yang lebih tinggi akan kredit dibandingkan dengan industri yang stabil atau mengalami penurunan. Keputusan untuk secara efektif membatasi jumlah kredit baru yang diberikan ke sektor tertentu bisa menghambat pertumbuhan di bidang-bidang ekonomi yang memberikan keunggulan komparatif bagi negara.

(ii) Kecukupan Modal: Rasio modal minimal merupakan aliran utama regulasi perbankan selama bertahun-tahun dan banyak penganjurnya seperti Kaufman (1999) menunjukkan bahwa leverage bank yang tinggi merupakan sumber kegagalan bank dan menyatakan bahwa peningkatan rasio modal minimal relatif tidak menimbulkan biaya namun merupakan cara yang efektif untuk menghindarkan bank dari pecahnya bubble. Pandangan bahwa tambahan modal tidak membutuhkan biaya didasarkan pada proposisi bahwa bank yang teregulasi (regulated bank) bisa mengeksploitasi rasio modal yang lebih rendah dibandingkan lembaga yang tidak teregulasi (unregulated institution) karena jaminan pemerintah secara implisit melalui asuransi deposito dan membawa rekomendasi penerapan yang lebih luas dari intervensi awal terstruktur, dengan rasio modal yang lebih tinggi sebagai elemen dasar dari strategi ini. 


\section{Kelemahan:}

- Meskipun Kaufman mungkin benar bahwa perubahan rasio modal bank pada dasarnya adalah masalah pricing dari perspektif pasar, namun biaya kredit tidak terpisah dari kombinasi utang/ekuitas bank tersebut. Menaikkan rasio modal akan menyebabkan kenaikan harga atau pengurangan kredit.

- Tidak ada panduan dalam kerangka kerja yang ada sekarang tentang berapa banyak modal yang dianggap memadai.

- Perlu pula diingat bahwa usulan intervensi awal terstruktur tidak diterima secara umum. Ada alasan kuat bagi penerapan usulan ini di negara-negara dimana hambatan regulasi telah menyebabkan kerugian berulang, atau dimana bank-bank tidak kooperatif dalam bekerja menyelesaikan masalah bersama dengan regulator. Meskipun India merupakan contoh yang baik terkait dengan hubungannya dengan regulator, namun manfaat intervensi awal terstruktur sangatlah bergantung pada situasi.

- Meksipun persyaratan modal yang lebih tinggi dan intervensi awal terstruktur bisa mengurangi biaya ledakan bubble, namun hal tersebut tidak menjawab pertanyaan tentang mengapa bubble terbentuk dan bagaimana cara mencegahnya.

(iii) Loan Loss Provisioning: Pada saat ekspansi ekonomi, kredit bank meningkat, sementara kerugian pinjaman (loan loss) dan provision for loan loss biasanya turun. Kecenderungan countercynical dari provisi ini timbul karena metodologi provisioning tradisional, berdasarkan pada provisi tetap dan spesifik, cenderung melihat ke belakang (backward looking), dan bukannya didasarkan pada ekspektasi kerugian di masa mendatang. Pendekatan tradisional dalam provisioning for loan didasarkan pada pandangan bahwa provisi harus mengurangi nilai aset pinjaman ke biaya yang lebih rendah dan nilai bersih yang direalisasikan. Dalam pendekatan ini provisi biasanya tidak dibuat sampai pinjaman terbukti macet (impaired). Perilaku cadangan dalam pendekatan tradisional menekankan pada boom dan bust cycle dan karenanya berkontribusi baik dalam menciptakan penggelembungan harga maupun dalam peledakannya. Namun pada tahun-tahun terakhir ini, bank mulai mengadopsi variasi yang dikenal sebagai "Dynamic Provisioning". Filosofi yang mendasari dynamic provisioning adalah bahwa provisi harus menutupi kerugian yang terduga, dan harus ada modal untuk menutupi kerugian yang tak terduga. Dynamic provisioning melihat kerugian terduga sebagai biaya dalam pemberian pinjaman. Dengan mengikuti alur pemikiran ini, suatu bank yang tidak mengakui kerugian terduga, "adalah sama seperti perusahaan asuransi yang menerbitkan premi dan kemudian berharap bahwa tidak seorangpun yang akan mengajukan klaim". ${ }^{39}$ 


\section{Kelemahan:}

- Sifat counter-cyclical dari metodologi provisioning tradisional telah menimbulkan kekhawatiran bagi regulator;

- Meskipun ada rekomendasi Komiter Basel tentang konsep kerugian terduga, namun provisioning cenderung tetap reaktif dan bukannya antisipatif, karena alasan-alasan yang terutama berkaitan dengan aturan perpajakan dan akuntansi di berbagai yurisdiksi;

- Konsep dynamic provisioning belum banyak diterima dan karenanya tidak dianggap sebagai suatu alternatif.

\section{KESIMPULAN}

Kerangka yang digunakan di sini adalah dalam bentuk sederhana / 'reduced form': akan lebih memuaskan untuk memodelkan proses intermediasi secara eksplisit, misalnya - dengan mempertimbangkan dimensi internasional. Namun pesannya sudah cukup jelas - bahwa kondisi kredit sangat mempengaruhi ekonomi dan langkah-langkah darurat untuk merestrukturisasi neraca melalui perubahan kebijakan merupakan hal yang penting dalam mengatasi masalah leverage yang berlebihan. Ini jauh berbeda dengan pandangan model konvensional - bahwa 'dampak memburuknya intermediasi keuangan cenderung terbatas' dan bisa diatasi hanya dengan penurunan suku bunga.

Peringatan dari Paul de Grauwe ${ }^{40}$ - model konvensional gagal untuk melihat masalah yang ada - membawa pesan lain. Bukan hanya neraca bank yang perlu direstrukturisasi: fondasi mikro dari makroekonomi juga memerlukan restrukturisasi dan juga perombakan kebijakan; dan mengakui fakta bahwa kerangka regulasi memiliki dampak yang jauh lebih mendalam dalam mempengaruhi penggelembungan harga aset daripada kebijakan moneter.

Sebagai pendekatan kebijakan regulasi alternatif, kami mencoba menelaah tiga kemungkinan respon regulasi dalam menangani bubble: pembatasan portofolio; penyesuaian dalam persyaratan modal; dan penyesuaian dalam persyaratan provisioning, dan berkesimpulan bahwa:

- Pendekatan pertama, yakni membuat pembatasan komposisi portofolio, berseberangan dengan prinsip-prinsip pengawasan perbankan modern berbasis risiko dan berpotensi menimbulkan biaya besar dalam hal dampaknya pada efisiensi ekonomi.

- Meskipun ada alasan untuk menggunakan penyesuaian dalam kecukupan modal sebagai alat counter-cyclical, namun biaya efisiensi yang timbul karena ketidaktepatan menjadi alasan untuk menolaknya.

40 As cited in "Asset Price Bubbles and Prudential Regulation", Working Paper 3, September 2001, Australian Prudential Regulation Authority, accessible at http://www.apra.gov.au/Policy/upload/Asset-Price-Bubbles-and-Prudential-Regulation-Sep2001.pdf. 
- Ada alasan yang lebih kuat untuk memperkenalkan rezim provisioning yang counter cyclical yang terutama dirintis atas kecenderungan pro-cyclical dari pendekatan tradisional terhadap provisioning dan juga fakta bahwa pendekatan provisioning yang counter-cyclical sesuai dengan hasil yang dihasilkan oleh model cyclically adjusted dynamic provisioning.

- Terakhir kami menemukan bahwa peran regulasi keuangan dalam mengendalikan kemunculan, dan kerusakan akibat, penggelembungan harga aset masih relatif terbatas.

Meskipun model regulasi yang ditawarkan tidak menjanjikan cakupan definitif dari peran regulasi kehati-hatian (prudent regulation) dalam mengendalikan kemunculan penggelembungan harga aset dan kerusakan finansial dari peristiwa tersebut, namun model ini memperlihatkan 3 hal, yakni, (1) bubble menimbulkan biaya bagi ekonomi; (2) ada hubungan kuat antara bubble dan perilaku bank; dan (3) hubungan ini bisa dikelola tanpa biaya melalui regulasi yang tepat. Dan kami merasa bahwa hal ini bisa membantu mengembangkan alternatif yang efektif dalam mengatasi masalah penggelembungan aset terutama di negara-negara berkembang seperti India. 


\section{DAFTAR PUSTAKA}

King, Ronald R.; Smith, Vernon L.; Williams, Arlington W. and van Boening, Mark V. (1993). "The Robustness of Bubbles and Crashes in Experimental Stock Markets". in R. H. Day and

P. Chen. Nonlinear Dynamics and Evolutionary Economics. New York: Oxford University Press. ISBN 0195078594. Also see, Lahart, Justin (2008-05-16). "Bernanke's Bubble Laboratory, Princeton Protégés of Fed Chief Study the Economics of Manias". The Wall Street Journal: p. A1 . avaialbe at http://online.wsj.com/article/SB121089412378097011.html. Tulipomania: The Story of the World's Most Coveted Flower \& the Extraordinary Passions It Aroused." Mike Dash (2001).

John O'Farrell, An Utterly Impartial History of Britain - Or 2000 Years of Upper Class Idiots In Charge (October 22 2007) (2007, Doubleday, ISBN 9780385611985). Also, see Charles Mackay, Extraordinary Popular Delusions and the Madness of Crowds (Harriman House Classics 2003), p. 65 \& 71.

Wolmar, C, 2007, Fire \& Steam: A History of the Railways in Britain, Atlantic Book (London) ISBN 978-1-84354-629-0.

Kenneth Ballinger: Miami Millions, Miami: (self published), 1936. p. 139.

Three Australian Asset-price Bubbles", The Reserve Bank of Australia, 2003. Available at http:/ /www.rba.gov.au/PublicationsAndResearch/2003/Simon.pdf.

Bank of Japan, "Asset Price Bubble in Japan in the 1980s: Lessons for Financial and Macroeconomic Stability" http://www.imes.boj.or.jp/english/publication/edps/2003/03-E15.pdf.

"Japan's Bubble Economy".http://www.sjsu.edu/faculty/watkins/bubble.htm.

Kaufman, GG., Krueger, TH., Hunter, WC. (1999). The Asian Financial Crisis: Origins, Implications and Solutions. Springer. ISBN 0792384725.

International Monetary Fund's report in World Economic Outlook, titled, "Growth and Institutions", published in April 2003, available at: http://www.imf.org/external/pubs/ft/weo/ 2003/01/index.htm

Identifying Asset Price Bubbles in the Housing Market in India - Preliminary Evidence, Reserve

Bank of India Occasional Papers, Vol. 27, No. 1 and 2, Summer and Monsoon 2006. Ibid. 
An In-Depth Analysis of the East Asian Crisis: Special Implications for India, Subhajit Sr., Indira Gandhi Institute of Development Research (IGIDR), 2008, accessible at http://papers.ssrn.com/ sol3/papers.cfm?abstract id=1152131.

International Monetary Fund's report in World Economic Outlook, titled, "Growth and Institutions", published in April 2003, available at http://www.imf.org/external/pubs/ft/weo/ 2003/01/index.htm.

Asset Price Booms and Monetary Policy", Carsten Detken and Frank Smets, European Central Bank (ECB), 2004, accessible at: http://papers.ssrn.com/sol3/papers.cfm?abstract id=533122. Rethinking Capital Regulation", Kashyap, A.K., R. Rajan and J.C Stein, 2008. Liquidity and financial cycles", Adrian, Tobias and Hyun Song Shin, 2007, Mimeo Princeton University.

The Panic of 2007", Gary Gorton, 2008, Yale School of Management and NBER, Prepared for the Federal Reserve Bank of Kansas City, Jackson Hole Conference, August 2008, accessible at http://www.kc.frb.org/publicat/sympos/2008/gorton.08.04.08.pdf.

Bank Restructuring: Lessons from the 1980s",Sheng, Andrew, Washington, D.C.: World Bank, 1996.

Why Paulson is wrong": Economists Voice, Zingales, Luigi, 2008, The Berkeley Electronic Press. Credit Cycles", Kiyotaki, Nobuhiro, and John Moore, Journal of Political Economy, 105, 1997. We aren't done yet: Comments on the financial crises and Bailout", Stiglitz, Joseph E, 2008, Economists' Voice: The Berkeley Electronic Press, (October).

Why Central Banks Should Burst Bubbles", Roubini, Nouriel, 2006, International Finance Journal. Synchronization risk and delayed arbitrage", Abreu, Dilip and Markus K. Brunnermeier,2002,Journal of Financial Economics, Vol. 66(2-3), pp. 341-360.; Also See "Bubbles and Crashes",Abreu, Dilip and Markus K. Brunnermeier, 2003, Econometrica, Vol. 71(1), pp. 173-204.

Housing and Business Cycle", World Economic Outlook, 2008 International Monetary Fund, accesible at http://www.imf.org/external/pubs/ft/weo/2008/01/index.htm.

Review of Annual Statement on Monetary Policy for the Year 2006-07, Reserve Bank of India, 2006.

Monetary Policy and Asset Price Volatility, Bernanke, Ben, and Mark Gertler, 1999, In New Challenges for Monetary Policy: A Symposium Sponsored by the Federal Reserve Bank of Kansas City: 77-128. Federal Reserve Bank of Kansas City.

Asset Prices and Central Bank Policy", Cecchetti, Stephen G., Hans Genberg, John Lipsky, and Sushil Wadhwani,2003, Journal of Money, Credit and Banking. 
Asset Price Bubbles and Prudential Regulation", Working Paper 3, September 2001, Australian Prudential Regulation Authority, accessible at http://www.apra.gov.au/Policy/upload/AssetPrice-Bubbles-and-Prudential-Regulation-Sep2001.pdf.

Anatomy of a Typical Financial Crisis", Charles Kindleberger, 1989, accessible athttp:// delong.typepad.com/egregious_moderation/2009/01/charles-kindleberger-anatomy-of-atypical-financial-crisis.html.

Financial Contagion", Franklin Allen and Douglas Gale, The Journal of Political Economy, Vol. 108, No. 1. (Feb., 2000), accessible at http://links.jstor.org/sici?sici=00223808\%28200002\%29108\%3A1\%3C1\%3AFC \%3E2.0.CO\%3B2-D.

Monetary Policy and Asset Price Volatility, Bernanke, Ben, and Mark Gertler, 1999, In New Challenges for Monetary Policy: A Symposium Sponsored by the Federal Reserve Bank of Kansas City: 77-128. Federal Reserve Bank of Kansas City.

Asset Price, Reversals, Economic Instability, and Monetary Policy", Bordo, M.D. and O. Jeanne, (2001), Paper presented at the Annual Meeting of the American Financial Association, New Orleans, January 7, 2001.

Asset Price Inflation and Monetary Policy", Schwartz, A. J.,(2001), Paper presented at the Annual Meeting of the American Financial Association, New Orleans, 7 January. Asset Price Bubbles and Monetary Policy', Kent, C. and P. Lowe, 1997, Reserve Bank of Australia, Research Discussion Paper 9709.

Managing Bank Capital',Matten, C, 2000, John Wiley \& Sons Ltd.,West Sussex.

As cited in "Asset Price Bubbles and Prudential Regulation", Working Paper 3, September 2001, Australian Prudential Regulation Authority, accessible at http://www.apra.gov.au/Policy/ upload/Asset-Price-Bubbles-and-Prudential-Regulation-Sep2001.pdf. 